\title{
Variability of in-stream and riparian storage in a beaded arctic stream
}

\author{
M. F. Merck, ${ }^{1}$ B. T. Neilson, ${ }^{1 *}$ R. M. Cory ${ }^{2}$ and G. W. Kling ${ }^{3}$ \\ ${ }^{1}$ Utah State University, Civil and Environmental Engineering, Utah Water Research Laboratory, 8200 Old Main Hill, Logan, UT 84321, USA \\ ${ }^{2}$ University of North Carolina at Chapel Hill, Environmental Sciences and Engineering, Gillings School of Global Public Health, 160 Rosenau Hall \\ Campus Box 7431, Chapel Hill, NC, 27599-7431, USA \\ ${ }^{3}$ University of Michigan, Department of Ecology and Evolutionary Biology, Ann Arbor, MI, 48109-1048, USA
}

\begin{abstract}
:
The extent and variability of water storage and residence times throughout the open water season in beaded arctic streams are poorly understood. Data collected in Imnavait Creek, a beaded stream located north of the Brooks Range in Alaska, were used to better understand the effects of in-pool and riparian storage on heat and mass movement through beaded streams. Temperature data of high spatial resolution within the pools and surrounding sediments were used with volumetric discharge and electrical conductivity to identify storage areas within the pools, banks, and other marshy areas within the riparian zone, including subsurface flow paths that connect the pools. These subsurface flows were found to alter water conductivity and the character of dissolved organic matter (DOM) in short reaches $(10 \mathrm{~s} \mathrm{of} \mathrm{m}$ ) while influencing the chemistry of downstream pools. During low flow periods, persistent stratification occurred within the pools due to absorption of solar radiation by DOM coupled with permafrost below and low wind stress at the pool surface. Additionally, one of the shallow pools $(<0.5 \mathrm{~m}$ depth $)$ remained stratified during higher flow periods and lower radiation inputs due to dense subsurface flows entering the bottom of the pools. This consistent separation of surface and bottom water masses in each pool will increase the travel times through this and similar arctic watersheds, and therefore will affect the evolution of water chemistry and material export. Copyright (C) 2011 John Wiley \& Sons, Ltd.
\end{abstract}

Supporting information may be found in the online version of this article.

KEY WORDS arctic hydrology; beaded stream; thermal stratification; hydrologic connectivity

Received 9 May 2011; Accepted 19 August 2011

\section{INTRODUCTION}

The rate of transport and fate of dissolved and particulate materials in surface waters are influenced by storage within hillslope, riparian, and transient zones, which includes in-channel and hyporheic storage (e.g. Bencala and Walters, 1983; Mulholland et al., 1990; Morrice et al., 1997; McNamara et al., 1998; McGlynn et al., 1999; Stieglitz et al., 2003; McGuire et al., 2007). These storage areas may be particularly important for terrestrial loss and aquatic export of nutrients in tundra environments (e.g. Brooks and Williams, 1999; McNamara et al., 2008), in part due to the extreme nutrient limitation experienced by both terrestrial and aquatic tundra ecosystems (Chapin et al., 1980; Kling, 1995). However, the challenge in understanding the function and impact of these storage areas lies in integrating the role of distinguishing features of tundra landscapes and hydrological dynamics with our current knowledge of how storage zones affect the movement of water and the alteration of its chemistry within a catchment.

*Correspondence to: Bethany Neilson, Civil and Environmental Engineering, Utah Water Research Laboratory, Utah State University, 8200 Old Main Hill, Logan, UT 84321, USA.

E-mail: bethany.neilson@usu.edu
In arctic regions, increases in depth of the active layer, the upper portion of the ground that thaws seasonally, in both hillslope and riparian zones during summer will create water storage locations. This new storage may be particularly important in early spring during snowmelt runoff when the active layer is at or near zero depth, and even small increases in depth create significantly more storage (McNamara et al., 1997; Edwardson et al., 2003). The influence of areas within the riparian zone on water and nutrient or carbon movement is important in temperate climates, especially due to flushing by rising groundwater levels (e.g. Inamdar et al., 2009). In their review of temperate-zone systems focusing on the hydrologic controls of nitrogen transport, Cirmo and McDonnell (1997) highlight the importance of these nearstream areas within the riparian zone both biogeochemically and hydrologically. Similarly, near-stream and transient storage areas within several arctic streams were shown to provide nitrate, ammonium, and carbon dioxide to the river channel (Edwardson et al., 2003). The diversity and dynamic nature of flow path distributions among these zones will likely influence the biogeochemistry of water leaving catchments.

Biogeochemical processing along water flowpaths can be understood in part using chemical tracers such as the 
spectral characterization of naturally occurring DOM (McKnight et al., 2003; Cory et al., 2011). Spectral analyses provide information on the amount of colored DOM (CDOM) using spectrophotometric absorbance, and on the 'chemical character' of fluorescing DOM (FDOM) using fluorescence excitation-emission matrix spectra (EEMs). Because the character of DOM depends on both its source and biochemical or photochemical reactions (e.g. Jaffe et al., 2008), the fluorescence signature of DOM has been used as a proxy to indicate shifts in DOM composition during hydrologic transport within a catchment (Hood et al., 2003; Miller et al., 2006; Huang and Chen, 2009) or across catchments (Cory et al., 2007). However, spectral measurements may also help distinguish specific water flow paths, especially in complicated systems where hillslope, riparian, and instream storage all affect hydrologic dynamics and water residence times.

In arctic alluvial and peat streams, Zarnetske et al. (2007) found that the greatest mean residence time within any particular transient storage zone occurred at low flow conditions and exponentially decayed with increasing discharge. Throughout their low-flow simulations, thaw depth was directly correlated with transient storage, while discharge inversely correlated with mean storage residence time; however, at higher flows discharge dominated the size and residence time of storage zones. More specifically, Edwardson et al. (2003) found the ratio of total transient storage area to channel area to be high in peat-bed, beaded arctic streams consisting of small pools connected by shallow chutes. This stream type is typically first order and has insignificant hyporheic exchange but large in-pool storage due to bead volume and low discharge (Edwardson et al., 2003). Although vertical stratification of water masses within stream beads has been reported (Irons and Oswood, 1992), the temporal and spatial extent of this stratification, its controls, and its potential impacts on water storage, stream residence time, and the isolation (physical and chemical) of water masses are unknown.

To investigate the influences of various storage mechanisms including pool stratification on water movement, residence times, and connectivity between the stream and riparian zone, we collected physical and chemical data in riparian areas and pools of a typical peatbed, beaded arctic catchment. We determined the storage and flow patterns in the riparian and in-pool areas during a dry period in the prolonged absence of precipitation, a wet period when sediments were saturated due to precipitation events, and a transition period between dry and wet conditions. We also determined the hydrologic connectivity among the hillslope water tracks, riparian areas, and stream, and demonstrated the extent and variability of in-stream storage due to stratification patterns within the pools.

\section{SITE DESCRIPTION}

Imnavait Creek, located in the Kuparuk River basin at $68.616^{\circ} \mathrm{N}$ latitude and $149.318^{\circ} \mathrm{E}$ longitude, is one of many beaded streams in the North Slope of Alaska which are formed when massive ground-ice deposits are exposed due to erosion by the stream (McNamara et al., 1998). In this particular stream, the frequency of pools is $\sim 13$ pools per $100 \mathrm{~m}$ of reach due to the relatively small size of the pools and short connecting chutes. Pool depths range from 0.12 to $2.7 \mathrm{~m}$ and surface areas from 1 to $323 \mathrm{~m}^{2}$.

This part of Alaska is wetland tundra and is completely underlain by up to several hundred meters of permafrost (Osterkamp and Payne, 1981). The top layer of soil, an organic peat layer $10-50 \mathrm{~cm}$ thick, overlies glacial till (Hinzman et al., 1991). The seasonally thawed active layer typically reaches depths of approximately $25-40 \mathrm{~cm}$ in this area, although depths of up to $100 \mathrm{~cm}$ have been recorded (Hinzman et al., 1991). Thus, the area is effectively isolated from deep groundwater, and the only subsurface storage and flow occurs in the shallow, unfrozen active layer (Edlund et al., 1990). Although rain events and the associated surface and subsurface runoff do occur during the summer season, the local hydrology is dominated by snowpack ablation and melting in spring (Kane et al., 1989). McNamara et al. (2008) found streamflow at Imnavait Creek during spring snowmelt to account for an average of $31-39 \%$ of the annual water flux, while Kane et al. (2004) found ranges of $23-71 \%$ with an average of $47 \%$. McNamara et al. (2008) also found the largest summer storm events produce $3-19 \%$ of the annual water flux and that snowmelt streamflow accounts for the highest annual nutrient flux. Water from precipitation events flows down slope as both overland and subsurface flow mainly through water tracks. Once the water reaches the riparian zone, the low-gradient marshy area adjacent to the pools and chutes, it enters Imnavait Creek as both surface and diffuse subsurface flow through the active layer (Kane et al., 2000).

The portion of Imnavait Creek studied is $\sim 30 \mathrm{~m}$ measured along the thalweg including three pools and accompanying connective chutes and two water tracks (Figure 1). In-stream flow travels from the southern portion of the study area northward through pool 4, out well-defined chute 5 , through pool 5 , out poorly defined chute 6 , through pool 6 , and lastly through another poorly defined chute 7 . Pools 4 and 6 were sampled intensively; they are of similar small size with respect to the range of pool sizes within the system and in close proximity to one another, but experience different hydro and thermal dynamics. While pool 4 only has one inlet and one obvious surface outlet chute, pool 6 has one surface inlet and outlet plus one major water track input that directly connects the west-facing hillslope to the pool. A second water track, draining a portion of the east-facing hillslope, flows into pool 5. Beyond these, an additional flow path was later identified that connects pool 4 to 6 (Figure 1), which we refer to as a side track. This side track includes both surface (during wet conditions) and subsurface (during both wet and dry conditions) flows depending on water levels in the riparian corridor. 

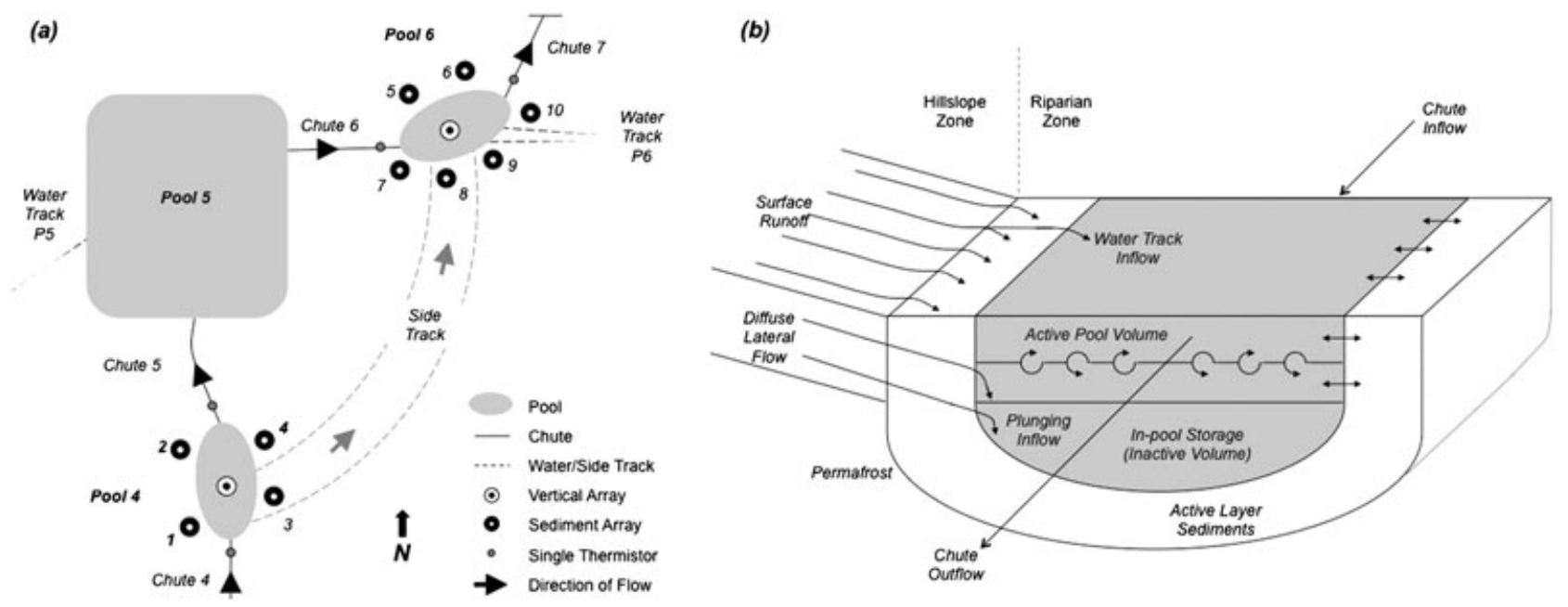

Figure 1. Site schematic (a) showing locations of field measurements and flow direction in a portion of Imnavait Creek in 2010. Chute discharges were measured in approximately the same locations as the inlet and outlet single thermistor locations. Water chemistry samples were collected within the top and bottom of each pool, within each chute, and in the subsurface near sediment arrays \#3, \#8, and \#10. Conceptual schematic of a pool (b) showing various flow paths and active versus inactive pool volumes

By 1 July 2010, the first day of the field study, there had been no precipitation in over two weeks, but there had been $32.5 \mathrm{~mm}$ since the end of snowmelt on 20 May (data from D. Kane). The air temperatures had been mostly above freezing since mid May. This weather resulted in dry upland and riparian areas and, therefore, very low in-stream flows. Neither the water tracks nor the side track contained surface flow during the initial dry portion of the field study. However, on 5 July, the rain began and persisted until the end of August. After only $\sim 20 \mathrm{~mm}$ of rain, both the water and side tracks were saturated and had some surface flow. Eventually, this nearly continuous precipitation resulted in completely saturated hillslopes, running water tracks, high in-stream flows, elevated stream water surfaces, and a saturated riparian area resulting in the side track being under several centimeters of surface water.

\section{METHODOLOGY}

The data collection effort within Imnavait Creek spanned from early July to late August and included a one-week intensive study followed by a one-month less intensive study. The intensive study included data describing hydrologic connectivity (e.g. chute flows and pool elevations), riparian and pool storage behavior (e.g. sediment and vertical temperature arrays), meteorological patterns within the watershed, and riparian and pool chemistry. The less intensive study continued data collection of only the sediment and vertical arrays and meteorological measurements.

\section{Hydrologic connectivity}

Due to variation in flow and a constantly changing wetted perimeter of the connective chutes throughout the one-week intensive study period, three different types of discharge measurements were used depending on water velocity, volumetric flow, and pool levels. The first several days of the study were dry and sunny; stream velocities were low, and discharge was measured with a 1-L beaker capturing water flowing over simple weirs installed at the inlet and outlet of each pool (Figure 1). When stream flow increased substantially, the small weirs were overtopped, and discharge was measured with a Marsh McBirney ${ }^{\circledR}$ Flo-Mate ${ }^{\mathrm{TM}}$ 2000 velocity meter at locations where the flow merged into a relatively uniform portion of the channel. Once the high flows had sufficiently mixed the pools, dilution gaging was performed using salt tracer injection to measure flows in pool 6 since the chute geometry precluded measurement with the velocity area method. Specific conductance, used as a surrogate for the conservative tracer concentrations, was measured using a YSI ${ }^{\circledR} 600$ LS or 600 XLM within each chute. A stage-discharge relationship was then determined using data from the in-pool depth measurements and chute flow measurements to produce a flow time series. Water surface elevations were measured using a YSI ${ }^{\circledR} 600 \mathrm{LS}$ sonde that contains a pressure transducer and was connected to a vented cable in order to correct for changes in atmospheric pressure.

\section{Riparian storage}

Sediment arrays were installed to establish wetting and drying patterns in the soils surrounding the pools in the riparian zone (Figure 1). In general, we use the term 'riparian zone' to include all stream bank and near-stream areas within the confines of the valley bottom $(\sim 25 \mathrm{~m}$ wide in our study area). Onset ${ }^{\circledR}$ HOBO $^{\circledR}$ Water Temp Pro V2 (Bourne, MA) thermistor temperature sensors were used to record the temperature in the sediment every $5 \mathrm{~min}$ (accuracy $=0.2^{\circ} \mathrm{C}$, resolution $=0.02{ }^{\circ} \mathrm{C}$ at $25^{\circ} \mathrm{C}$ ). The installation methods and depths used were similar to those described in Neilson et al. (2009). The sensors were placed in capped and perforated 1.5" PVC pipe at depths of at 3, 9, and $20 \mathrm{~cm}$. The sensors were isolated vertically from each other so as to measure temperature at a specific depth and to 
allow for lateral flow through the pipe but prohibit vertical flow within the pipe. There were four sediment arrays buried around pool 4 (for a total of 12 sensors) and six sediment arrays buried around pool 6 (for a total of 18 sensors) (Figure 1).

\section{In-pool storage}

$\mathrm{HOBO}^{\circledR}$ Water Temp Pro V2 temperature sensors were also placed vertically within pools 4 and 6 (Figure 1). Temperature in the water column was recorded every 5 min at fixed depths approximately $3 \mathrm{~cm}$ apart in order to capture precise timing and depths of pool stratification. The vertical arrays in pools 4 and 6 included 19 and 13 sensors, respectively. Sensors were wrapped in aluminum foil to avoid heating due to radiation penetration within the water (Neilson et al., 2010). Temperature in the water column was also verified several times using a Fluke ${ }^{\circledR}$ 5610 thermistor (American Fork, UT) (accuracy $=0.01{ }^{\circ} \mathrm{C}$ and resolution $=0.0001{ }^{\circ} \mathrm{C}$ over 0 to $100^{\circ} \mathrm{C}$ ) by measuring water temperature at depths of $1 \mathrm{~cm}$ increments. These measurements were consistent with those recorded by the $\mathrm{HOBO}^{\circledR}$ sensors verifying that the sensors were unaffected by solar radiation. To understand how residence times vary with stratification patterns, the active pool volumes (the upper mixed portion of the pool) and chute flows were used in a simple calculation of the mean residence times of water ( $\tau=$ Volume/Discharge) throughout the study period for pools 4 and 6 .

\section{Meteorological measurements}

Meteorological measurements were recorded on an hourly basis on the west-facing ridge of the basin approximately 1 $\mathrm{km}$ upstream of the study site (D. Kane, unpublished data). Air temperature, relative humidity, and wind speed were measured at 1, 3, and $10 \mathrm{~m}$ heights using Campbell Scientific ${ }^{\circledR}$ Model 207 (Logan, UT) temperature (accuracy = $0.4{ }^{\circ} \mathrm{C}$ ) and humidity (accuracy $=5 \%$ ) sensors and Met One ${ }^{\circledR}$ Model 104A anemometers (accuracy $=0.11 \mathrm{~m} \mathrm{~s}^{-1}$ over $0-45 \mathrm{~m} \mathrm{~s}^{-1}$ ). Net solar radiation was measured using a Swissteco ${ }^{\circledR}$ Model S-1 net radiometer (accuracy $=2.5 \%$ ), and precipitation was measured at intervals of $0.1 \mathrm{~mm}$ using a Texas Electronics tipping bucket with an Alter windshield.

\section{Water chemistry}

Water samples from surface flows (top and bottom of pools 4 and 6 and within connecting chutes) and soil waters (near sediment array sites \#3, \#8, \#10, Figure 1) were collected by dipping bottles or using a $20-\mathrm{cm}$ long steel needle for withdrawing soil water, and stored in polyethylene bottles. Specific conductivity and temperature were measured using a Consort K912 (Turnhout, Belgium) (accuracy of $0.5 \%$ full scale and resolution of $0.01 \mu \mathrm{S} / \mathrm{cm}$ and $\left.0.1^{\circ} \mathrm{C}\right)$. Sub-samples for analysis of CDOM and FDOM were filtered in the field using pre-combusted Whatman GF/F filters immediately following collection. These samples were filtered into opaque polyethylene bottles for storage until analysis within $24 \mathrm{~h}$. First, the CDOM was characterized via its $\mathrm{UV}$-visible (UV-vis) absorbance spectrum, obtained for each sample in a 1-cm quartz cuvette using an Optics USB4000 spectrophotometer. Based on high UV-vis absorbance spectra the samples were diluted with laboratory grade deionized water prior to fluorescence analysis; this allowed correction for the inner filter effect following guidelines in Miller et al. (2010). Immediately following the UV-vis absorbance measurement, an EEM was collected on each diluted water sample in the same cuvette to characterize the FDOM. EEMs on each water sample were measured using a Fluoromax-4 fluorometer (Horiba Scientific) following the procedures of Cory et al. (2010). Briefly, EEMs were collected from each sample over an excitation and emission range of $240-450 \mathrm{~nm}$ by $5 \mathrm{~nm}$ and $320-550 \mathrm{~nm}$ by $2 \mathrm{~nm}$, respectively, using an integration time of $0.1 \mathrm{~s}$. EEMs of each water sample were corrected for inner-filter effects using the respective UV-vis absorbance spectrum (McKnight et al., 2001). Instrument-specific excitation and emission corrections in Matlab (ver. 7.7) were conducted following Cory et al. (2010) via a user-generated rhodamine spectrum for excitation correction (DeRose et al., 2009) and a manufacturer-provided emission correction spectrum (Horiba Scientific). Similarly analyzed blank EEMs, collected from laboratory grade deionized water and free of detectable fluorescence emission, were subtracted from sample EEMs to minimize the influence of water Raman peaks. Lastly, intensities in corrected sample EEMs were converted to Raman units (Stedmon et al., 2003). Bottle leaching tests with deionized water demonstrated that there was no detectable fluorescence from the sample bottles.

From the absorbance spectrum, we calculated the Napierian absorption coefficient at $300 \mathrm{~nm}\left(\mathrm{a} 300, \mathrm{~m}^{-1}\right)$ and the slope ratio (SR) following Helms et al. (2008). In our dataset of samples from this system, a300 and SR have analytical variation on the order of $\sim 2 \mathrm{~m}^{-1}$ and $\sim 0.04$, respectively. From each sample EEM, we calculated the fluorescence index (FI; McKnight et al., 2001) according to Cory et al. (2010); the FI has an analytical variation on the order of $\sim 0.01$ at most (see Cory et al., 2011). Replicate measurements of EEMs from this system have shown that the analytical variability in EEM intensities ranges from 0.002 to 0.05 RU at most, depending on excitation and emission wavelength (unpublished data).

\section{RESULTS}

\section{Hydrologic connectivity}

Under dry conditions, all flows were less than $1 \mathrm{~L} \mathrm{~s}^{-1}$ (Figure 2a). Chute inflows to pool 4 were consistently greater than chute outflows suggesting a loss that is likely attributable to the side track. Conversely, chute outflows from pool 6 were greater than chute inflows, which is reasonable given the additional subsurface inflow from the side and water tracks. Once the precipitation began, in-stream flows increased, and water levels in the pools rose, which resulted in surface flow in the side track 

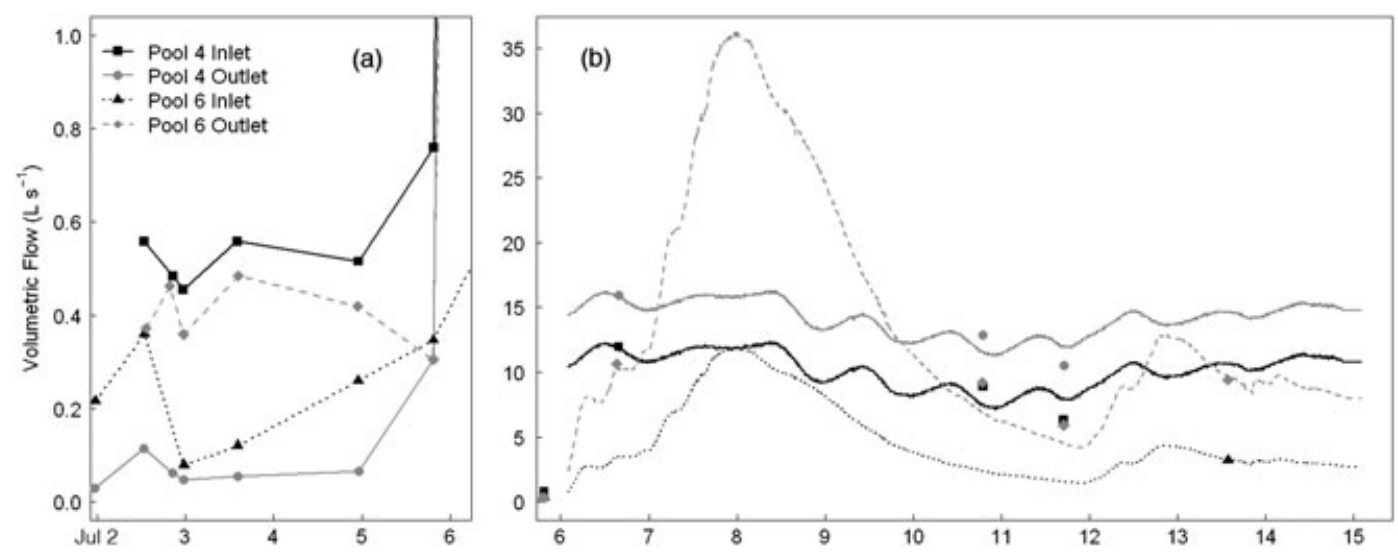

Figure 2. Chute discharge during low (a) and high (b) flows. Observations are shown as symbols and results from the stage-discharge relationship are shown as lines (high flows only)

(Figure 2b). Outflows from pool 6 continued to be greater than inflows, but the flow relationship for pool 4 switched, and pool 4 outflows became greater than pool 4 inflows. However, of particular interest is that outflows from pool 6 were less than inflows to pool 4, except under peak flow conditions, which indicates water losses (likely due to riparian storage) within the study reach.

Table I and Figure 3 show that surface waters in the pools experienced some warming moving downstream during dry, low-flow conditions in early July. Deeper waters within the pools and subsurface flows within the side and water tracks were considerably cooler, and specific conductivities were much less than those in surface waters. The 'dry conditions' data (2 July; Figure 3) show a gradual increase in the surface temperature from chute 4 to 6 , but then a slight decrease from chute 6 to 7 . The surface water in pool 6 was similar to its inlet water (chute 6); however, the deep water temperature was between pool 6 inlet temperature and the side and water track subsurface temperatures, which is considerably cooler. The temperature of pool 6 outlet (chute 7) was between the temperatures of the surface and deep water within pool 6. A similar pattern was seen in the specific conductivity data for 2 July. During wet, high-flow conditions (11 and 23 Aug; Table I), pool temperatures and specific conductivities were much more homogeneous. However, note that for both days, the temperatures and specific conductivities of pool 6 outlet (chute 7) were not between the range of surface and deep pool temperatures and specific conductivities. Also, on 23

Table I. Temperature and specific conductivity of surface and soil water samples for 2 July, 11 August, and 23 August 2010 at various locations within the study reach (see Figure 1). In general, in-stream water is diluted and warmed as it flows through the system; more so during drier periods. During the dry period, cooler water with lower specific conductivity was found deeper in the pools and in the subsurface.

During the wet period, cooler water with lower specific conductivity was found only in the water tracks draining the hillslope

\begin{tabular}{|c|c|c|c|c|c|c|c|}
\hline \multirow[b]{3}{*}{ Location Within Study Site } & & \multirow{2}{*}{\multicolumn{2}{|c|}{$\begin{array}{l}\text { DRY } \\
2 \text { July }\end{array}$}} & \multicolumn{4}{|c|}{ WET } \\
\hline & & & & \multicolumn{2}{|c|}{11 August } & \multicolumn{2}{|c|}{23 August } \\
\hline & & $\begin{array}{c}\text { Spec Cond } \\
\left(\mu \mathrm{S} \mathrm{cm}^{-1}\right)\end{array}$ & $\begin{array}{c}\text { Temp } \\
\left({ }^{\circ} \mathrm{C}\right)\end{array}$ & $\begin{array}{l}\text { Spec Cond } \\
\left(\mu \mathrm{S} \mathrm{cm} \mathrm{cm}^{-1}\right)\end{array}$ & $\begin{array}{c}\text { Temp } \\
\left({ }^{\circ} \mathrm{C}\right)\end{array}$ & $\begin{array}{l}\text { Spec Cond } \\
\left(\mu \mathrm{S} \mathrm{cm}^{-1}\right)\end{array}$ & $\begin{array}{c}\text { Temp } \\
\left({ }^{\circ} \mathrm{C}\right)\end{array}$ \\
\hline Chute 4 (most upstream) & & 498 & 18.9 & 169.1 & 10.4 & 287 & 7 \\
\hline \multirow[t]{2}{*}{ Pool 4} & Surface & 501 & 19.2 & 169.5 & 10.3 & 285 & 7.2 \\
\hline & Deep & 482 & 15.2 & 169.2 & 10.4 & 286 & 7.1 \\
\hline Chute 5 (pool 4 outlet) & & 501 & 19 & 168.8 & 10.4 & 285 & 7.1 \\
\hline \multirow[t]{2}{*}{ Side Track (out of pool 4) } & Surface & - & - & 169.2 & 10.4 & 285 & 7.2 \\
\hline & Subsurface & 495 & 13.8 & - & - & 237 & 8 \\
\hline \multirow[t]{2}{*}{ Water Track (into pool 5) } & Surface & - & - & - & - & 25.3 & 5.1 \\
\hline & Subsurface & - & - & - & - & 78.7 & 5.8 \\
\hline \multirow[t]{2}{*}{ Pool 5} & Surface & - & - & 168.3 & 10.3 & 278 & 7.2 \\
\hline & Deep & - & - & 168.5 & 10.2 & 279 & 7.1 \\
\hline Chute 6 (pool 6 inlet) & & 463 & 19.6 & 168.5 & 10.3 & 281 & 6.9 \\
\hline \multirow[t]{2}{*}{ Side Track (into pool 6) } & Surface & - & - & 170 & 10.2 & 275 & 7.5 \\
\hline & Subsurface & 422 & 10.0 & - & - & 240 & 6.9 \\
\hline \multirow[t]{2}{*}{ Water Track (into pool 6) } & Surface & - & - & 98.4 & 9.0 & 76.5 & 6.5 \\
\hline & Subsurface & 178.6 & 10.6 & - & - & 103.7 & 7.5 \\
\hline \multirow[t]{2}{*}{ Pool 6} & Surface & 463 & 19.5 & 169 & 10.3 & 278 & 7.2 \\
\hline & Deep & 439 & 12.0 & 169.5 & 10.2 & 281 & 7.1 \\
\hline Chute 7 (most downstream) & & 450 & 19.2 & 165.2 & 10.7 & 275 & 7.6 \\
\hline
\end{tabular}




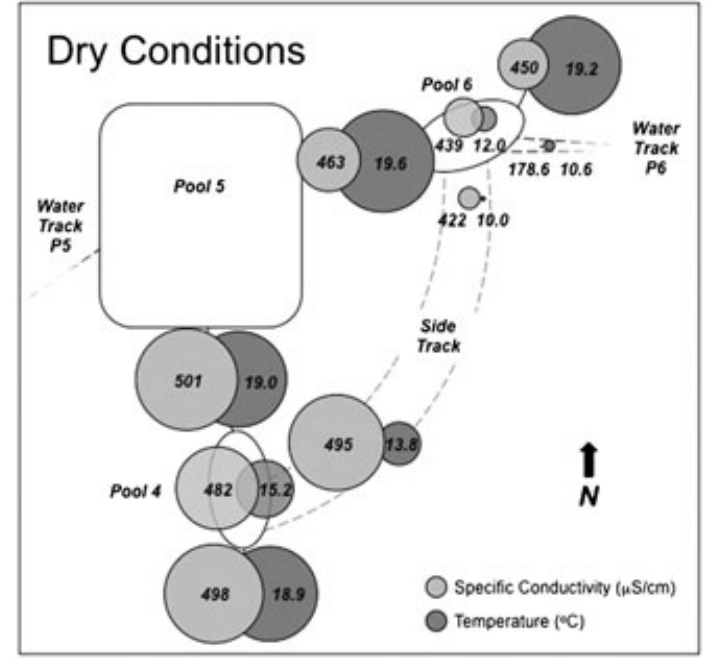

Figure 3. Locations and values of specific conductivity and temperature of surface and soil water samples during low flows (2 July 2010). The size of the dot is relative to magnitude, and the numeric value is shown inside or next to the dot. Measurements shown within the pools reflect water samples taken from bottom depths

August, the temperatures of the subsurface flows within the water tracks were higher than their surface water temperatures due to very cold air temperatures.

\section{Riparian storage}

Sediment array temperature data are displayed in Figure 4 (pool 6) and Supplemental Figure 1 (pool 4). Arrays \#1 and \#2 near pool 4 and \#5 and \#6 near pool 6 were on higher ground than the rest of the arrays. The sediments surrounding these arrays were initially relatively dry, but became either fully or partially saturated for the latter part of the study. Although all the arrays show strong diel temperature fluctuation in the top sensor, arrays at higher elevations (\#5 and \#6, Figure 4) initially recorded the largest fluctuations. In all arrays, the middle sensors recorded noticeable diel fluctuations while the bottom sensor recorded very subtle diel fluctuations. As expected, there is a time lag in the diel fluctuations from top to middle to bottom sensors which is due primarily to the time required for heat conduction through the soil. In the riparian zone, the thaw depths around these pools ranged from 40 to $70 \mathrm{~cm}$ resulting in observed sediment temperatures (the deepest at $20 \mathrm{~cm}$ ) that were influenced more by atmospheric conditions than by the frozen ground deep below. All sensors in all arrays showed muted fluctuations once precipitation saturated the riparian zone, and both conduction and advection were influencing the temperature responses. For example, the isotherms collapsed together around 6, 12, 20, and 29 July and very obviously around 7 August (Figure 4). However, the return to well-defined diel fluctuation patterns took progressively longer after each of these events.

To further illustrate the filling and draining of the riparian zone, we compared temperature time series from the riparian sediments, pool surface, and ambient air. Array \#6 is furthest from pool 6 both laterally and in elevation. Temperature from the top sediment sensor in this array was similar to the air temperature until precipitation began on 27 July (Figure 5), after which the sediment temperatures more closely matched the temperatures of surface water in pool 6; this indicates that the dry riparian sediments were infiltrated by rising pool

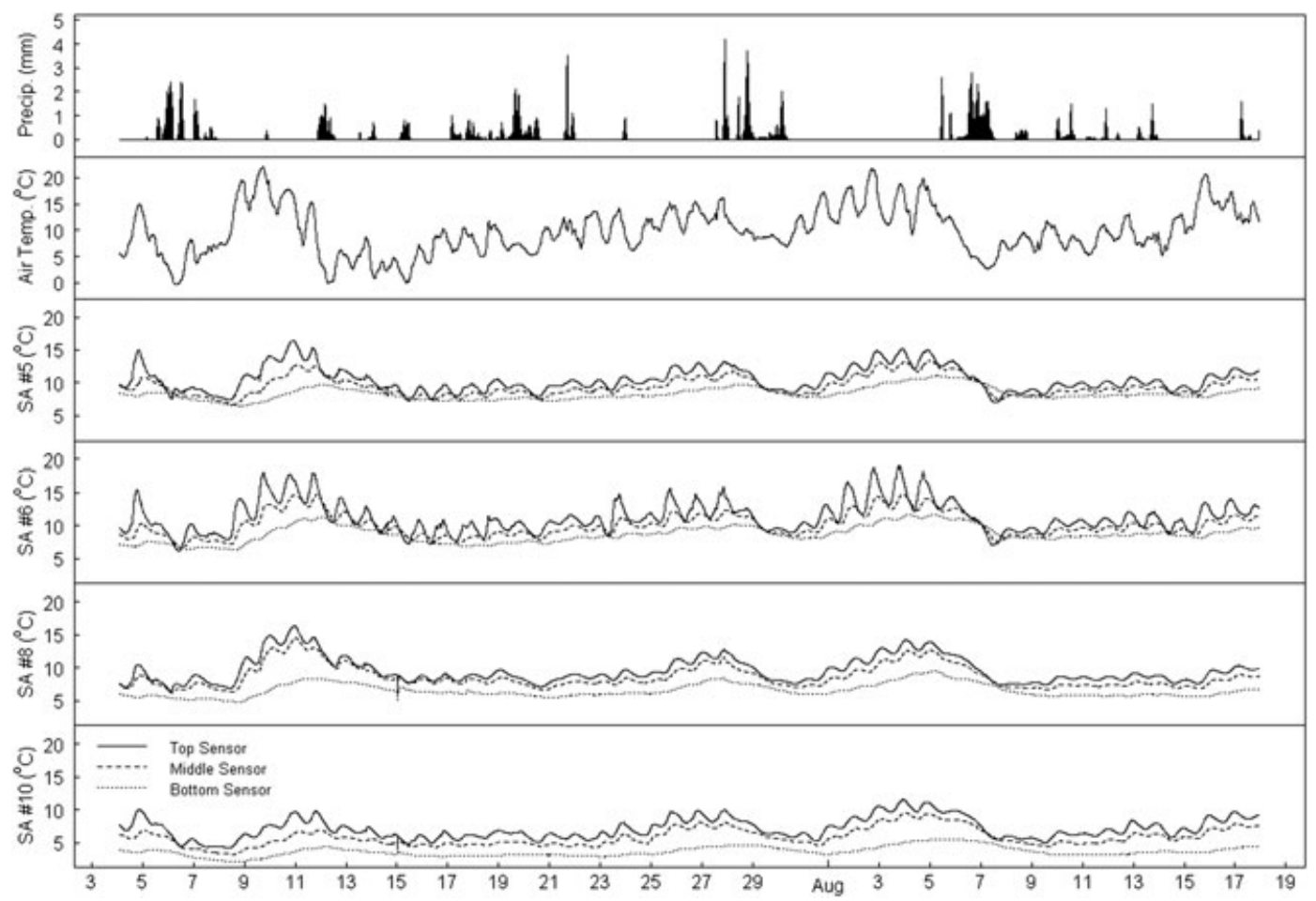

Figure 4. Time series of hourly precipitation and air temperature in Imnavait Basin and sediment array temperatures around pool 6. The top sensor was approximately $3 \mathrm{~cm}$ below the sediment surface; middle at $\sim 9 \mathrm{~cm}$; bottom at $\sim 20 \mathrm{~cm}$. See the site schematic (Figure 1) for array locations. Arrays \#5 and \#6 were installed in higher elevation 'dry' sediment and arrays \#8 and \#10 were installed in lower 'wet' sediment 
water. Approximately 2 days after the precipitation stopped (1 August), the top layer of sediment had drained and once again responded to air temperature. This pattern

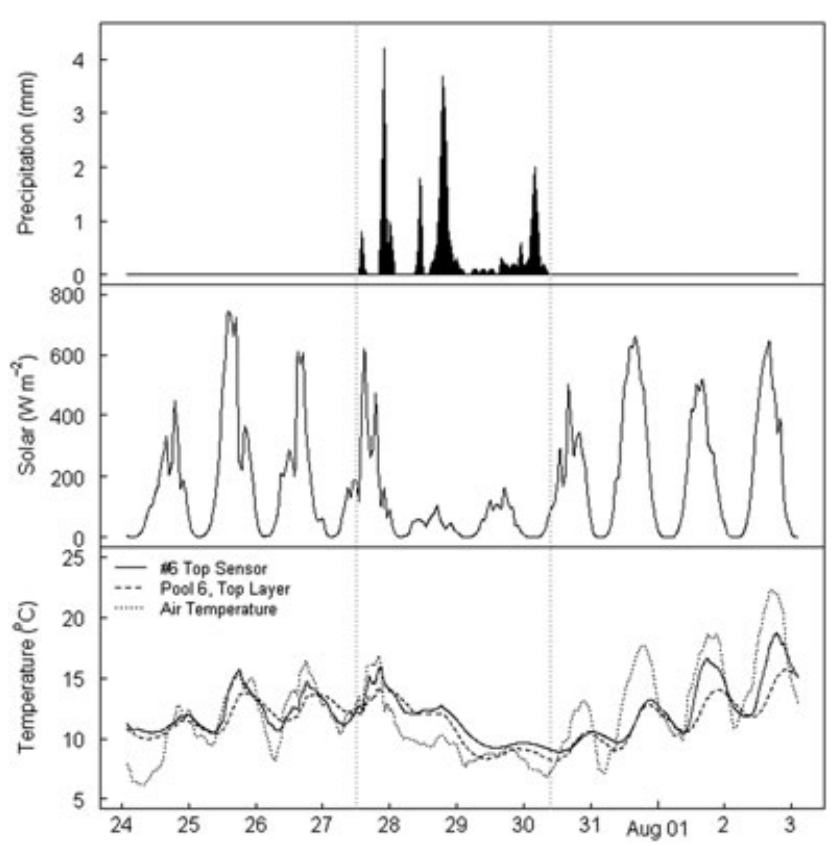

Figure 5. Hourly precipitation, solar radiation, and temperatures from the $3 \mathrm{~cm}$ depth sensor in sediment array \#6 (a 'dry' array) near pool 6, the top layer of water in pool 6, and the air temperature. Note the cycle of drywet-dry: 24-27 July (dry), 27-30 July (wet), 30 July - 3 Aug (dry). During the dry period (i.e. no precipitation), the solar radiation was high, and the sediment temperature mimicked the air temperature. During the wet period (i.e. precipitation event), the solar radiation was low, and the sediment temperature mimicked the top layer of the pool. It took approximately two days after the rain stopped for the sediment temperatures to once again mimic the air temperature recurred with every precipitation event and is evidence of the wetting and drying of riparian sediments that influenced storage and flushing of stream water and solutes.

\section{In-pool storage}

At the beginning of the field study, when conditions were dry and flows were low, both pools 4 and 6 were strongly stratified throughout the entire water column during the day, although the upper portion of each pool would mix nightly (Figures 6 and 7). Around the time of the rain event of 5-8 July, air temperature was low (Figure 4), solar radiation was low and wind speeds tended to increase (Figure 6), stream flows increased (Figure 2), and the pools mixed (Figures 6 and 7). However, after the rain stopped and the sun reappeared (e.g. 9-10 July), only pool 6 restratified substantially. Throughout the study period, pool 6 consistently cycled between mixing and stratifying, while pool 4 primarily remained mixed during high-flow conditions (Figures 6 and 7). It is probable that pool 6 restratified more strongly due to the addition and plunging of denser water from the side and water tracks into the bottom of the pool. For example, during stratified periods the average density of the surface water was approximately $0.998 \mathrm{~g} \mathrm{~cm}^{-3}$, while the average density of water entering the pool was $1.000 \mathrm{~g} \mathrm{~cm}^{-3}$ based on the temperatures observed at $20 \mathrm{~cm}$ within the surrounding sediments, and $0.999-1.000 \mathrm{~g} \mathrm{~cm}^{-3}$ based on the temperatures at $3 \mathrm{~cm}$ depth. Thermal profiles within the upper portion of the pool suggested that differences in density as small as $0.00002 \mathrm{~g} \mathrm{~cm}^{-3}$ between sensors resulted in mixing or plunging water.

The combination of stratification and mixing with changing in-stream flows drastically affected the active pool

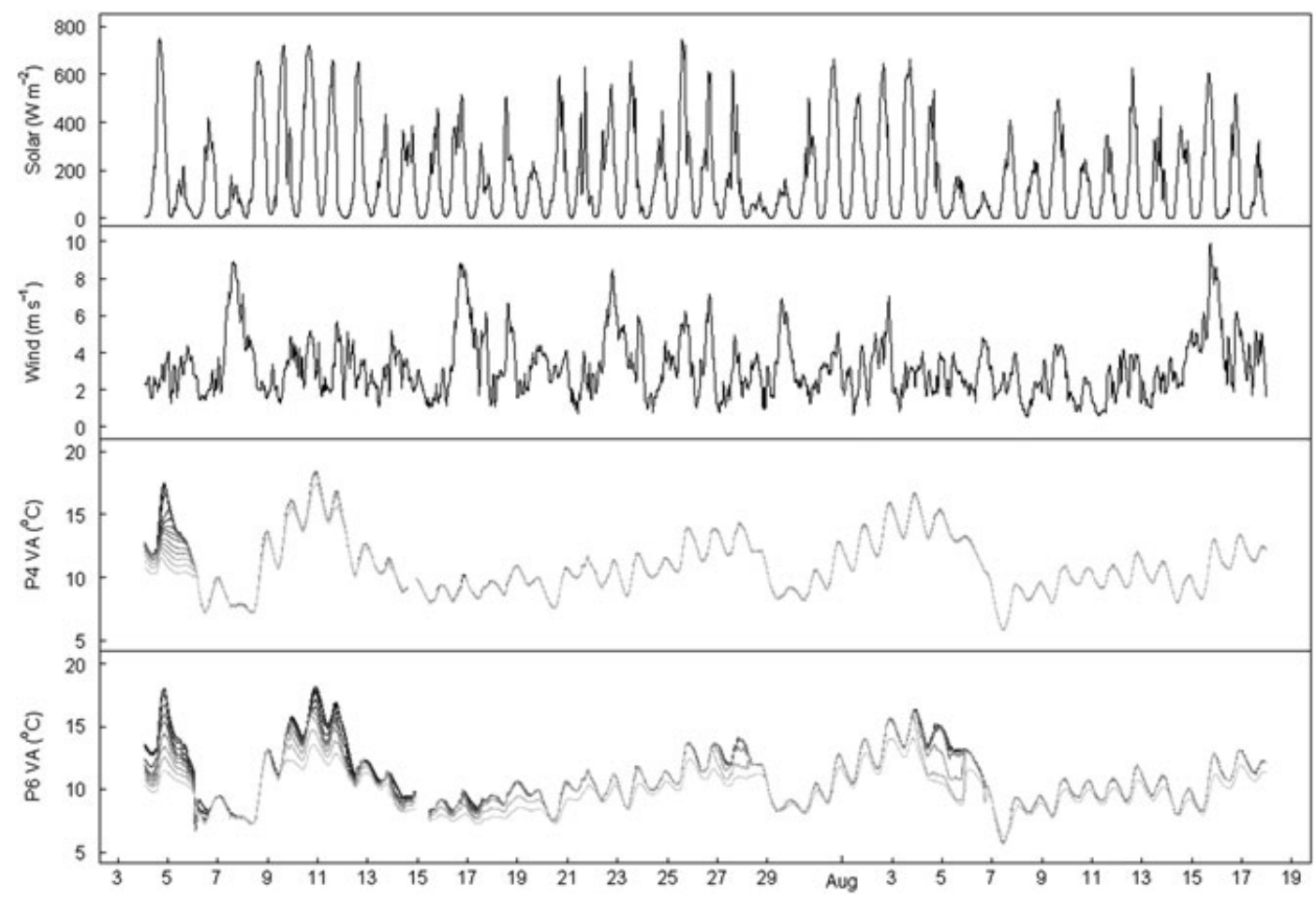

Figure 6. Time series of solar radiation and wind speed in Imnavait Basin and vertical array temperatures in pools 4 ( $\sim 0.35 \mathrm{~m}$ deep) and 6 ( $\sim 0.5 \mathrm{~m}$ deep). The sensors were placed every $3 \mathrm{~cm}$ within the water column. The darkest line represents the top sensor; subsequent lines become lighter with depth of each sensor 


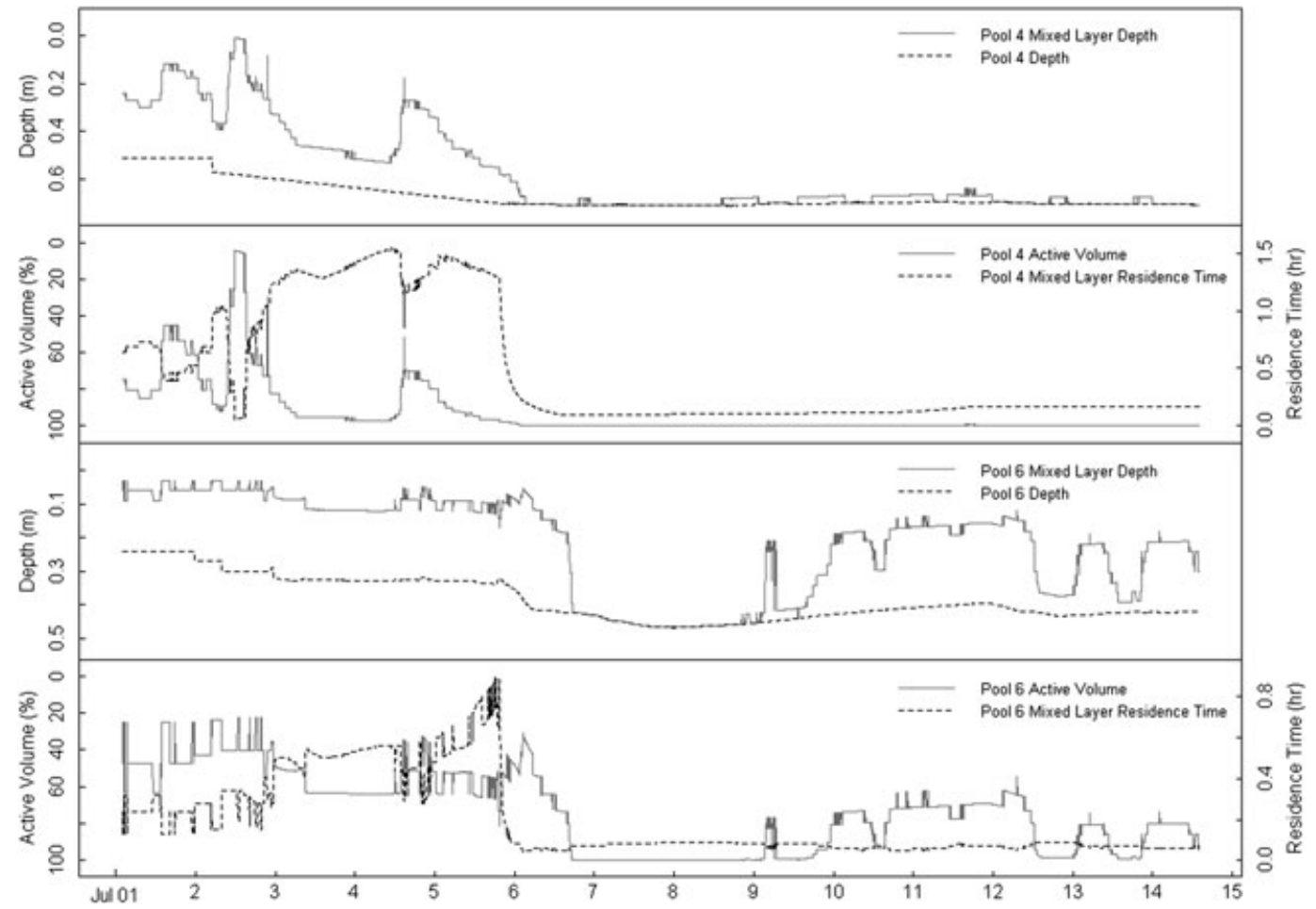

Figure 7. Depth of the mixed layer, percent active volume, and residence time of pools 4 and 6 from 1-15 July 2010. 'Mixed layer' is the upper portion of the pool that is considered completely mixed as opposed to stratified. 'Active volume' is the volume of the mixed layer. Residence time was calculated using active volume of the pool and measured chute flow (Figure 2)

volumes (Figure 7). Because of this, residence times of the upper mixed layers in the pools ranged from only a few minutes to almost $1.5 \mathrm{~h}$. While both pools reflect mixing of only a portion of the total pool volume during low flows (1-6 July), pool 6 was obviously more strongly stratified because its active pool volume during this time (20-60\%) was less than that of pool 4 (50-90\%). This remained true under high flow conditions, where pool 4 stayed nearly completely mixed (100\% active pool volume), while the deep water in pool 6 stratified at times (70-100\% active pool volume).

\section{Pool and subsurface flow chemistry}

The potential for alteration of stream chemistry during passage through the subsurface side track and during pool stratification was examined using patterns of FDOM measured from several sites on 2 July at the end of the dry conditions. Table II provides the a300, FI, and SR values. Values of a300, indicating the amount of CDOM in the samples, varied consistently between surface and bottom waters in the pools, and subsurface soil waters. Surface waters had relatively low values $\left(33-37 \mathrm{~m}^{-1}\right)$ which increased in the bottom waters to a value of $49 \mathrm{~m}^{-1}$ in pool 4 and $119 \mathrm{~m}^{-1}$ in pool 6 . The higher value in pool 6 bottom water probably reflects the high CDOM of inflows entering pool 6 from the subsurface side track and water track (values of $459 \mathrm{~m}^{-1}$ and $425 \mathrm{~m}^{-1}$, respectively). The FI is a proxy for FDOM source and aromaticity, and the $\mathrm{SR}$ is a proxy for CDOM molecular weight (see McKnight et al., 2001, and Helms et al., 2008, for a full description). For our purposes, both measures show that surface waters in the pools and chutes are fairly

Table II. Spectral characteristics of DOM of surface and soil water samples collected on 2 July 2011. Values for absorbance at $300 \mathrm{~nm}$ wavelength $\left(\mathrm{a} 300, \mathrm{~m}^{-1}\right)$; the fluorescence index and the slope ratio have no units (see text)

Chute 4 (most upstream)

Pool 4

Chute 5 (pool 4 outlet)

Side Track (out of pool 4)

Side Track (into pool 6)

East Water Track (into pool 6)

Chute 6 (pool 6 inlet)

Pool 6

Chute 7 (most downstream)

$\begin{array}{lr} & 33 \\ \text { Surface } & 33 \\ \text { Deep } & 49 \\ & 34 \\ & 108 \\ & 459 \\ & 425 \\ \text { Surface } & 33 \\ \text { Deep } & 37 \\ & 119 \\ & 35\end{array}$

$\begin{array}{ll}1.46 & 0.76 \\ 1.46 & 0.70 \\ 1.46 & 0.78 \\ 1.46 & 0.73 \\ 1.46 & 0.61 \\ 1.52 & 0.44 \\ 1.46 & 0.53 \\ 1.47 & 0.75 \\ 1.46 & 0.84 \\ 1.49 & 0.57 \\ 1.47 & 0.73\end{array}$


similar in character, while the subsurface side track into pool 6 had the highest FI value (1.52) and the lowest SR value (0.44) of all samples. The bottom of pool 6 reflected these extremes by having the second highest FI value (1.49) and a low SR value of 0.57. Somewhat surprisingly, the water track into pool 6 had an FI value the same as surface water (1.46), but a low SR value of 0.53 similar to the side track. The results of all three measures show that the water exiting pool 4 into the side track is strongly altered in its DOM amount and character by the time it reaches pool 6 .

The EEMs of samples from the surface and bottom of pools 4 and 6 , the beginning and end of the side track, and the water track flowing into pool 6 are shown in Figure 8. Three general patterns are clear from the EEM data (consistent with the quantitative measures in Table II). First, when both pools were stratified, the character of the bottom water FDOM had diverged from the surface water (bottom waters had 15\% higher fluorescence intensity, slight blue-shift in the predominant excitation and emission peak positions). In addition, primarily surface water was leaving the pool outlets due to both stratification and the shallow depth of the chute entries within the pools. The result was similar EEMs observed for both the surface and chute outlet samples. However, in pool 6, the divergence of surface and bottom water is also likely related to the subsurface inflows. Second, the water leaving pool 4 is quickly altered (within $1 \mathrm{~m}$ from the pool) by the riparian zone soil in the side track (compare $22 \%$ higher intensity in Figure 8d with intensities in Figure $8 \mathrm{a}$ and $8 \mathrm{~b}$ and the much higher a300 and lower SR values in Table II). Additionally, this alteration continues and by the end of the side track, just before it moves into pool 6, the FDOM has increased by close to $50 \%$ in intensity (i.e. amount) and has shifted its distribution of fluorescent compounds characterized by substantially higher emission intensities primarily at the predominant peak at low excitation wavelengths $(E x=240-250 \mathrm{~nm})$. Shifts in intensities and peak positions in this region of the EEM $(E x / E m=240-250 / 350-450 \mathrm{~nm})$ have been attributed to a change in redox state (Cory and McKnight, 2005; Miller et al., 2006; Fimmen et al., 2007) or to a combination of moieties ranging from aromatic amino acids to fulvic acids associated with terrestrial plants or microbial source materials (Cory and McKnight, 2005); regardless of the precise attribution of this shift in intensity and distribution, there is a substantial chemical alteration along this subsurface flow path. Third, the bottom water in pool 6 shows the influence of inflows from either or both the side track and the water track; the intensity is higher in this bottom water, specifically at low excitation wavelengths of $240-250 \mathrm{~nm}$. This coincides with similar shifts in the side track and water track but not in the pool 6 surface water (compare Figure $8 \mathrm{~h}$ with $8 \mathrm{e}$,
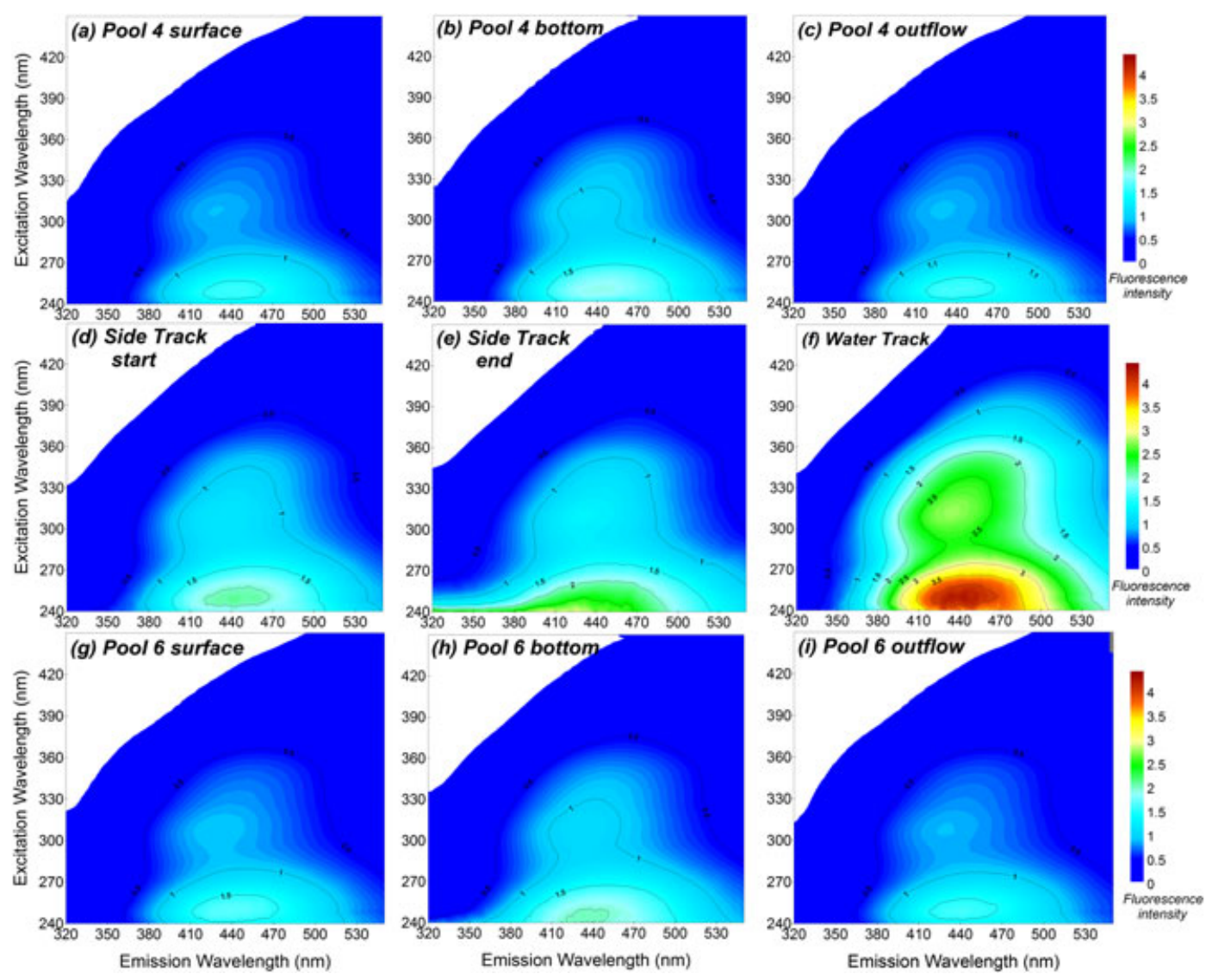

Figure 8. Fluorescence excitation-emission matrices from pools and pool outlets, subsurface water from the side track start (at sediment array \#3, panel d) and end (at sediment array \#8, panel e), and water track subsurface water (at sediment array \#10, panel f) flowing into pool 6 . All samples were collected on 2 July 2010, and fluorescence intensities (in Raman Units, RU) are plotted on a common scale for comparison between samples 
$8 \mathrm{f}$, and $8 \mathrm{~g}$ ). These results are all consistent with the idea that changes in in-stream storage due to pool stratification, coupled with subsurface water flow leaving and reentering pools downstream, have the potential to reinforce pool stratification and alter stream water chemistry.

\section{DISCUSSION}

Our analysis of the variability in riparian and in-stream storage and flow focused on comparing a dry period, a wet period, and the transition in between. At the start of the field study, the basin had been dry for 17 days. The water levels in the pools were very low, there was minimal flow within the chutes between the pools, and there was no surface flow within the water tracks. In addition, some of the sediments surrounding the pools were dry. At this time of year, the available hillslope and riparian storage is at its greatest. The only potential for movement of water and export of solutes laterally into the stream was due to minimal subsurface flow from melting ice lenses or active layer thaw, both of which resulted in small in-stream flows.

During this initial dry period, water exiting pool 4 into the side track (Figure 1) appeared to be mostly surface water from the pool based on the similarities in specific conductivities (Table I, Figure 3). These data show that the subsurface conductivity within the side track is similar to that within the top of pool 4. Some additional, but limited, information regarding temperatures at the pool surface (Figure 6) and at the $3 \mathrm{~cm}$ depth of sediment array \#3 at the start of the side track (Supplemental Figure 1) suggest similar infiltration water from the surface of pool 4 into the side track. This infiltrated water becomes subsurface lateral flow on its path from pool 4 to 6 . Slight increases in pool levels show that while pool storage increased over the dry period, the volume added over these days was approximately 100 times smaller than the observed losses within pool 4.

The loss of flow from pool 4 , as seen from the large disparities in inlet and outlet flows for both pools 4 and 6 during this time (Figure 2a), is attributable to the increased amount of water being input to and stored in the side track on its subsurface traverse to pool 6. During this traverse, the temperature of this subsurface lateral flow was cooled by the underlying permafrost. Once this flow reached the end of the side track, it entered pool 6 , primarily plunging to the bottom due its greater density than pool surface water. This added volume to the already cool bottom layer of pool 6 and therefore assisted in keeping the pool partially stratified. We anticipate that these subsurface and cold surface inputs from other riparian inflows or water tracks draining the hillslope would have a similar effect on pool stratification during a variety of flow conditions. In addition, during the dry and initial portion of the transition period, this relatively large movement of water from the stream and pool surfaces into unsaturated riparian soils will serve to increase the overall residence time of water in the system.
The water track draining the west-facing hillslope experienced only subsurface flow during the dry period and contained water of relatively low specific conductivity (178.6 $\mu \mathrm{S} / \mathrm{cm} ; 2$ July, Table I and Figure 2). In contrast, water in the side track entrance (near pool 4) had a much higher specific conductivity of $495 \mu \mathrm{S} / \mathrm{cm}$, which was diluted to $422 \mu \mathrm{S} / \mathrm{cm}$ at its exit (near pool 6). This change in chemistry could be due to several processes: (1) addition of water from the more dilute water track lowered the conductivity, (2) the water residence time in the side track being long enough that the water near pool 6 was older than that near pool 4 (i.e. from a previous, more dilute flow event), or (3) it experienced some biogeochemical change along the flow path. Calculation of the mean residence time of water in the side track $(\tau=V / Q)$ assuming a porosity for the peat and mineral sediments within the riparian zone of 0.7 (Hinzman et al., 1991), a soil volume for the side track of $\sim 40 \mathrm{~m}^{3}$ based on measured thaw depths, and the differences in measured chute discharges, gives residence times on the order of one to several days during the low flow periods when water is entering the side track from pool 4. Because the residence times even at low flows were so short, it is unlikely that the low conductivity water entering pool 6 was a relic water mass from a previous flow event. It is likely that there was dilution from the adjacent hillslope which would lower the conductivity of the side track entering pool 6 , but we cannot rule out that biogeochemical processes may also play a role in changing the conductivity. For example, we did measure a change in the character of the DOM (Table II, Figure 8), and it is well known that wetland organisms can alter the conductivity of water due to uptake processes (e.g. Clymo, 1963; Soudzilovskaia et al., 2010). Therefore, we suggest that both dilution and biogeochemical changes along the flow path were the dominant influences on subsurface water chemistry.

Storage within the pools during low flow conditions was similar in nature to that of the side track riparian storage in that there was little or slowed movement of water into and out of the lower layers of these pools when stratified (Figure 6). Because the warmer inlet water consistently skimmed the pool surface during the day (Table I; Figures 3, 6, and 7), there was minimal advective mixing between the warm surface and cold lower layers during low flows. At night, lower air temperatures and minimal solar radiation resulted in heat loss from the pool surface and caused the collapse of isotherms at the surface of the pools, creating a diel mixing pattern within the upper layers of pool 4 and less consistent mixing patterns within pool 6 (Figure 6). As shown clearly in the diel variability in the mixed layer depth and active pool volume for pool 4 (Figure 7), the chute inflows mixed deeper at night, but the strongly stratified periods for both pools showed no evidence of complete mixing of the surface waters. We suggest that the primary cause for stratification within these pools is the rapid attenuation of solar heat by high concentrations of DOM near the surface of the pools, thus creating a 
warmer upper layer. The stratification is further strengthened by the effects of conduction with the frozen soils below the pools (creating a cooler bottom layer). Small amounts of exchange with the bottom layers were likely occurring due to diffusive exchange with the water in the upper layers, or perhaps some entrainment of water from plunging lateral inflows. However, this exchange was insufficient to collapse the stratification or homogenize the water chemistry and resulted in extremely long residence times of these bottom waters unless a complete mixing event occurred. Observations in 2009 and 2011 from larger pools (unpublished data) with lower vertical measurement resolution show that strong stratification also occurs within these pools and that higher flows due to rainfall and runoff are insufficient to mix the entire pool. This suggests that the mixing patterns and in-pool storage we report here could be of even more importance when considering the entire ranges of pool volumes in this stream.

Under low flow conditions the differences in active pool volume between the two pools was likely due to lateral inflows into pool 6 from the water and side track. However, similar to the findings of Zarnetske et al. (2007), during high flows, the in-pool residence times plummet for both pools. Because there had been no rain in the multiple weeks prior to our initial measurements, the water and accompanying solutes in the bottom layer of the pools were likely built up for at least several weeks. This temporal lag in pool water replacement highlights the effects of in-stream storage on residence times, and illustrates that sufficient time allowed the divergence of water chemistry between pool surface and bottom waters (Figure 8). This divergence could be due to biogeochemical processes occurring within the pools, or to the isolation and preservation of water masses from an earlier point in time that were representative of previous stream chemistry.

In addition to shifts in water chemistry due to pool stratification during the dry period, there were clear shifts in water chemistry along subsurface flow paths in the riparian zone. These chemistry shifts occurred over very short distances as surface water moved from pool 4 into the subsurface of the side track, and the absorbance and fluorescence data show both increased amounts and a shift in composition of DOM (Table II, Figure 8 d, e). Because the DOM was altered within 1-2 $\mathrm{m}$ after leaving pool 4 , it is likely that increases in DOM quantity and shifts in DOM composition are due to in-soil processing rather than to solely hydrologic inputs of water with a different composition. However, as this water moved toward pool 6 , it is probable that addition of water from other sources, such as a hillslope water track, contributed to the continued shifts in DOM chemistry. This interpretation is similar to that used to explain shifts in FDOM levels and distribution in an alpine stream channel influenced by hyporheic exchange (Miller et al., 2006). Miller et al. (2006) concluded that shifts in FDOM along the stream channel could not be attributed to conservative mixing alone, but instead were due to input of DOM derived from the hyporheic zone.
When stratified, the DOM chemistry of bottom water in pool 6 showed a clear influence from the subsurface side track and hillslope water track (Table II, Figure 8). However, once this bottom water was mixed to the surface and exported from the pool, its chemistry was altered in a way consistent with photochemical destruction of FDOM in surface waters. Such photochemical destruction of FDOM has been shown to occur on timescales similar to water transit times in our system (Cory et al., 2007). This characteristic photochemical destruction of DOM is highlighted by comparing the higher FDOM intensities and CDOM absorbances in the soil water of the side track and water track with lower intensities in the surface waters and outflows from both pools (Table II, Figure 8), as has been shown in similar soil and surface waters (Cory et al., 2007). Although we have no time series of FDOM changes in riparian zone DOM through the summer (nor do any exist for any system to our knowledge), it is likely that photochemistry in addition to in-stream storage, riparian zone flow paths, and water residence times will be important in determining the chemistry of organic materials exported from at least beaded streams if not all streams.

Once precipitation began on 5 July, the available hillslope and riparian storage, which was primarily subsurface during dry conditions, started to fill. It took approximately two days before the water tracks consistently produced surface flow and in-stream flows started to increase. During this transition between dry and wet conditions, the sediments that were initially dry became progressively more saturated with stores of water from the rising levels of the adjacent pools, cold infiltrated rain, and lateral hillslope water (e.g. arrays shown in Figure 4); this situation is similarly described in Bense and Kooi (2004). Once saturated, additional surface storage was apparent within the riparian zones. These conditions, coupled with cold air temperatures, minimal radiation, and higher wind speeds resulted in cooling of riparian sediments and mixing of the pools (Figure 6).

After the initial rain event on 5 July, pool 4 switched from losing water to the surrounding riparian zone to gaining water (Figure 2). In addition, the top layer of adjacent sediment became saturated as is evident by the sudden drop and collapse of temperatures recorded by the sensors in all of the sediment arrays (Figure 4). These events reflect filling of the available hillslope and riparian storage and therefore subsequent rain became runoff. However, this initial event did not raise the level of the pools enough to be higher than the top sensor in the sediment arrays. It was not until the second rain event on 12 July that the sediment became fully and continually saturated and the pool levels rose. Because the top sensors in the sediment arrays were then at the same approximate elevation as the pool level, the top sediment temperatures and surface pool temperatures were nearly the same for a number of weeks as illustrated for a later time period in Figure 5.

After the transition period and filling of the active layer, the hillslope and riparian areas became completely saturated, and most of the precipitation became surface 
runoff. All water and side tracks maintained continuous surface flow, the pools filled, in-stream flow increased significantly (Figure 2), and all subsurface storage, including riparian storage, appeared to be at capacity. The resulting increased in-stream flows created turbulent conditions in the chutes and pools and further aided in mixing the layers within each pool (Figure 6). Complete mixing of the pools was initially achieved on 7 July at a flow rate of approximately $15 \mathrm{~L} \mathrm{~s}^{-1}$. Once completely mixed, the solutes in the bottom layer would be entrained in the main stream flow. With higher flow rates and water surfaces, the export of these solutes from the pools would be relatively quick and the only remaining in-pool storage would be stagnant areas near the edges of the flooded pools.

Both surface and subsurface flow paths within our study reach changed depending on whether the hillslope and riparian areas were dry or saturated. Under dry conditions, the hydrologic connectivity of the hillslope to the riparian zone was indirect through minimal diffuse lateral flow, consistent with modeling studies of Imnavait basin (Stieglitz et al., 2003). Saturated conditions facilitated direct hydrologic connectivity through hillslope surface runoff and surface flow in the water tracks. In some cases, the flow from the water tracks also directly connected the hillslopes to the pools within the stream.

Due to increasingly larger volumes of available storage in the thawing active layer surrounding the stream as summer progressed, water from the hillslope was stored in the riparian areas before being exported to the stream as diffuse lateral flow during dry conditions. Side tracks, an additional form of connectivity and transient storage within the riparian zone, would allow water from the pools to follow subsurface preferential flow paths during low-flow conditions. Conversely, during high-flow conditions, elevated surface waters would saturate the riparian area sediments and once again become riparian storage. The pool overflow would also become surface flow within the side tracks.

We found that hydrological connectivity in this system is both direct, through water tracks and runoff, and indirect, through diffuse lateral flow, and there is significant riparian storage of hillslope water. This riparian storage can subsequently influence in-pool storage through lateral inputs either to surface or bottom waters in the pools. Conversely, when unsaturated, the available storage in the riparian zone can be influenced by increasing pool levels. This filling or draining of riparian zone storage can affect downstream transport of materials particularly since the mean residence times of water in the riparian zone (calculated in a manner similar to that of the side track) ranged from $\sim 5$ weeks to $\sim 1$ day at the extremes of low versus high flow, respectively. This means that while transient storage in the form of hyporheic exchange has been found to be insignificant in peat-bed beaded streams (Irons and Oswood, 1992; Edwardson et al., 2003), our findings indicate that lateral inputs and losses can notably impact the amount and effects of in-pool storage as well as longitudinal transport.

\section{CONCLUSION}

As expected, the hydrologic connectivity of the hillslope to the riparian zone is both direct, through water tracks and runoff, and indirect, through diffuse lateral flow, and results in riparian storage of hillslope water. However, we found that riparian and hillslope storage can also subsequently influence in-pool storage through subsurface lateral inputs. Conversely, when unsaturated, the available storage in the riparian zone can be influenced by in-pool drainage when in-stream flow and water levels increase.

Dry conditions with low flows facilitated greater in-pool storage and increased water residence time. This is primarily due to strong thermal stratification which produced large stores of cooler water with long residence times in the bottom layers of the pools. However, even under high flow conditions, stratification was still observed in pools influenced by cold, lateral inflows. In the earlier portion of the thaw season, this water has the potential to be nutrient rich as it may be retained from the spring melt (cf. McNamara et al., 2008). Wet conditions with high flow resulted in complete or nearly complete mixing of the pools, which resulted in large volumes of in-stream waters flushing the long-term, in-pool storage.

Our results show that the hydrologic connectivity of arctic watersheds with beaded streams, and therefore the storage and export of water and nutrients from and within the watershed, is complex and quite dynamic. Overall, we found that storage and residence times of water in the riparian zone and in-pool areas within our study site were highly variable and may influence the timing of solute export and the evolution of water chemistry in this and similar systems.

\section{ACKNOWLEDGMENTS}

We thank Jen Kostrzewski and Doug Kane for their help with data collection. Funding came from the Inland Northwest Research Alliance, the Utah Water Research Laboratory, and the National Science Foundation (Arctic LTER, NSF-DEB 1026843; NSF-OPP 1023270; and NSF-DEB 0639805).

\section{REFERENCES}

Bencala KE, Walters RA. 1983. Simulation of solute transport in a mountain pool-and-riffle stream: a transient storage model. Water Resources Research 19(3): 718-724. DOI: 10.1029/WR019i003p00718.

Bense VF, Kooi H. 2004. Temporal and spatial variations of shallow subsurface temperature as a record of lateral variations in groundwater flow. Journal of Geophysical Research 109: B04103. DOI: 10.1029/ 2003JB002782.

Brooks PD, Williams MW. 1999. Snowpack controls on nitrogen cycling and export in seasonally snow-covered catchments. Hydrological Processes 13(14-15): 2177-2190. DOI: 10.1002/(SICI)1099-1085 (199910)13:14/15 < 2177::AID-HYP850 > 3.0.CO;2-V.

Chapin FS III, Miller PC, Billings WD, Coyne PI. 1980. Carbon and nutrient budgets and their control in coastal tundra. In An Arctic Ecosystem: the Coastal Tundra at Barrow, Alaska, Brown J, Miller PC, Tieszen LL, Bunnell FL (eds). Dowden, Hutchinson \& Ross: Stroudsburg; 458-482. 
Cirmo C, McDonnell J. 1997. Linking the hydrologic and biogeochemical controls of nitrogen transport in near-stream zones of temperate-forested catchments: a review. Journal of Hydrology 199(1-2): 88-120. DOI: 10.1016/S0022-1694(96)03286-6.

Clymo RS. 1963. Ion exchange in Sphagnum and its relation to bog ecology. Annals of Botany 27: 309-324.

Cory RM, McKnight DM. 2005. Fluorescence spectroscopy reveals ubiquitous presence of oxidized and reduced quinones in dissolved organic matter. Environmental Science and Technology 39(21): 8142-8149. DOI: 10.1021/es0506962.

Cory RM, McKnight DM, Chin YP, Miller P, Jaros CL. 2007. Chemical characteristics of fulvic acids from Arctic surface waters: microbial contributions and photochemical transformations. Journal of Geophysical Research 112: G04S51. DOI: 10.1029/2006JG000343.

Cory RM, Miller MP, McKnight DM, Guerard JJ, Miller PL. 2010. Effect of instrument-specific response on the analysis of fulvic acid fluorescence spectra. Limnology and Oceanography: Methods 8: 67-78. DOI: 10.4319/ lom.2010.8.67.

Cory RM, Boyer EW, McKnight DM. 2011. Spectral Methods to Advance Understanding of Dissolved Organic Carbon Dynamics in Forested Catchments. In Forest Hydrology and Biogeochemistry: Synthesis of Past Research and Future Directions, Ecological Studies 216, Levia DF et al. (eds). 115-135: DOI: 10.1007/978-94-007-1363-5_6.

DeRose PC, Smith MV, Mielenz KD, Blackburn DH, Kramer GW. 2009. Characterization of Standard Reference Material 2940, Mn-ion-doped glass, spectral correction standard for fluorescence. Journal of Luminescence 129(4): 349-355. DOI: 10.1016/j.jlumin.2008.10.017.

Edlund SA, Woo M-K, Young KL. 1990. Climate, hydrology and vegetation patterns. Hot Weather Creek, Ellesmere Island, Arctic Canada. Nordic Hydrology 21: 273-286. DOI: 10.2166/nh.1990.020.

Edwardson KJ, Bowden WB, Dahm C, Morrice J. 2003. The hydraulic characteristics and geochemistry of hyporheic and parafluvial zones in Arctic tundra streams, north slope, Alaska. Advances in Water Resources 26(9): 907-923. DOI: 10.1016/S0309-1708(03)00078-2.

Fimmen RL, Cory RM, Chin YP, Trouts TD, McKnight DM. 2007. Probing the oxidation-reduction properties of terrestrially and microbially derived dissolved organic matter. Geochimica et Cosmochimica Acta 71(12): 3003-3015. DOI: 10.1016/j.gca.2007.04.009.

Helms JR, Stubbins A, Ritchie JD, Minor EC, Kieber DJ, Mopper K. 2008. Absorption spectral slopes and slope ratios as indicators of molecular weight, source, and photobleaching of chromophoric dissolved organic matter. Limnology and Oceanography 53(3): 955-969

Hinzman LD, Kane DL, Gieck RE, Everett KR. 1991. Hydrologic and thermal properties of the active layer in the Alaskan Arctic. Cold Regions Science and Technology 19(2): 95-110. DOI: 10.1016/ 0165-232X(91)90001-W.

Hood E, McKnight DM, Williams MW. 2003. Sources and chemical character of dissolved organic carbon across an alpine/subalpine ecotone, Green Lakes Valley, Colorado Front Range, United States. Water Resources Research 39(7): 1188. DOI: 10.1029/2002WR001738

Huang W, Chen RF. 2009. Sources and transformations of chromophoric dissolved organic matter in the Neponset River Watershed. Journal of Geophysical Research 114: G00F05, DOI: 10.1029/2009JG000976

Inamdar S, Rupp J, Mitchell M. 2009. Groundwater flushing of solutes at wetland and hillslope positions during storm events in a small glaciated catchment in western New York, USA. Hydrologic Processes 23(13): 1912-1926. DOI: 10.1002/hyp.7322.

Irons JG III, Oswood MW. 1992. Seasonal temperature patterns in an arctic and two subarctic Alaskan (USA) headwater streams. Hydrobiologia 237(3): 147-157. DOI: 10.1007/BF00005847.

Jaffe R, McKnight DM, Maie N, Cory R, McDowell WH, Campbell JL. 2008. Spatial and temporal variations in DOM composition in ecosystems: the importance of long-term monitoring of optical properties. Journal of Geophysical Research 113: DOI: 10.1029/ 2008JG000683

Kane DL, Hinzman LD, Benson CS, Everett KR. 1989. Hydrology of Imnavait Creek, an arctic watershed. Holarctic Ecology 12(3): 262-269. DOI: 10.1111/j.1600-0587.1989.tb00845.x.

Kane DL, Hinzman LD, McNamara JP, Zhang Z, Benson CS. 2000. An overview of a nested watershed study in Arctic Alaska. Nordic Hydrology 31(4-5): 245-266. DOI: 10.2166/nh.2000.015.

Kane DL, Gieck RE, Kitover DC, Hinzman LD, McNamara JP, Yang D. 2004. Hydrological cycle on the North Slope of Alaska. In Northern Research Basins Water Balance, Kane DL, Yang D (eds). IAHS Publication 290, IAHS Press: Wallingford; 224-236.
Kling GW. 1995. Land-water linkages: the influence of terrestrial diversity on aquatic systems. In The Role of Biodiversity in Arctic and Alpine Tundra Ecosystems, Chapin FS III, Korner C (eds). Springer: Berlin; 297-310.

McGlynn B, McDonnell JJ, Shanley J, Kendall C. 1999. Riparian zone flowpath dynamics during snowmelt in a small headwater catchment. Journal of Hydrology 222(1-4): 75-92. DOI: 10.1016/S0022-1694(99) 00102-X.

McGuire KJ, Weiler M, McDonnell JJ. 2007. Integrating tracer experiments with modeling to assess runoff processes and water transit time. Advances in Water Resources 30(4): 824-837. DOI: 10.1016/ j.advwatres.2006.07.004.

McKnight DM, Boyer EW, Westerhoff PK, Doran PT, Kulbe T, Andersen DT. 2001. Spectrofluorometric characterization of dissolved organic matter for indication of precursor organic material and aromaticity. Limnology and Oceanography 46(1): 38-48. DOI: 10.4319 / lo.2001.46.1.0038.

McKnight DM, Hood E, Klapper L. 2003. Trace organic moieties of dissolved organic material in natural waters. In Aquatic Ecosystems: Interactivity of Dissolved Organic Matter, Findlay SEG, Sinsabaugh RL (eds). Elsevier Science: USA; 71-96.

McNamara JP, Kane DL, Hinzman LD. 1997. Hydrograph separations in an arctic watershed using mixing model and graphical techniques. Water Resources Research 33(7): 1707-1719. DOI: 10.1029/ 97WR01033.

McNamara JP, Kane DL, Hinzman LD. 1998. An analysis of streamflow hydrology in the Kuparuk River Basin, Arctic Alaska: a nested watershed approach. Journal of Hydrology 206(1-2): 39-57. DOI: 10.1016/S0022-1694(98)00083-3.

McNamara JP, Kane DL, Hobbie JE, Kling GW. 2008. Hydrologic and biogeochemical controls on the spatial and temporal patterns of nitrogen and phosphorus in the Kuparuk River, arctic Alaska. Hydrological Processes 22(17): 3294-3309. DOI: 10.1002/hyp.6920.

Miller MP, Simone BE, McKnight DM, Cory RM, Williams MW, Boyer EW. 2010. New light on a dark subject: comment. Aquatic Sciences 72: 269-275. DOI: 10.1007/s00027-010-0130-2.

Miller MP, McKnight DM, Cory RM, Williams MW, Runkel RL. 2006. Hyporheic exchange and fulvic acid redox reactions in an alpine stream/ wetland ecosystem, Colorado Front Range. Environmental Science and Technology 40(19): 5943-5949. DOI: 10.1021/es060635j.

Morrice, JA, Valett HM, Dahm CD, Campana ME. 1997. Alluvial characteristics, groundwater-surface water exchange and hydrological retention in headwater streams. Hydrological Processes 11(3): 253-267. DOI: 10.1002/(SICI)1099-1085(19970315)11:3<253:: AID-HYP439>3.0.CO;2-J.

Mulholland PJ, Wilson GV, Jardine PM. 1990. Hydrogeochemical response of a forested watershed to storms: effects of preferential flow along shallow and deep pathways. Water Resources Research 26(12): 3021-3036. DOI: 10.1029/WR026i012p03021.

Neilson BT, Stevens DK, Chapra SC, Bandaragoda C. 2009. Data collection methodology for dynamic temperature model testing and corroboration. Hydrological Processes 23(20): 2902-2914. DOI: 10.1002/hyp.7381.

Neilson BT, Hatch CE, Ban H, Tyler SW. 2010. Solar radiative heating of fiber-optic cables used to monitor temperatures in water. Water Resources Research 46: W08540. DOI: 10.1029/2009WR008354.

Osterkamp TE, Payne MW. 1981. Estimates of permafrost thickness from well logs in northern Alaska. Cold Regions Science and Technology 5 (1): 13-27. DOI: 10.1016/0165-232X(81)90037-9.

Soudzilovskaia NA, Cornelissen JHC, During HJ, van Logtestijn RSP, Lang SI, Aerts R. 2010. Similar cation exchange capacities among bryophyte species refute a presumed mechanism of peatland acidification. Ecology 91: 2716-2726.

Stedmon CA, Markager S, Bro R. 2003. Tracing dissolved organic matter in aquatic environments using a new approach to fluorescence spectroscopy. Marine Chemistry 82: 239-254. DOI: 10.1016/ S0304-4203(03)00072-0.

Stieglitz M, Shaman J, McNamara J, Engel V, Shanley J, Kling GW. 2003. An approach to understanding hydrologic connectivity on the hillslope and the implications for nutrient transport. Global Biogeochemical Cycles 17(4): 1105. DOI: 10.1029/2003 GB002041.

Zarnetske JP, Gooseff MN, Brosten TR, Bradford JH, McNamara JP, Bowden BW. 2007. Transient storage as a function of geomorphology, discharge, and permafrost active layer conditions in Arctic tundra streams. Water Resources Research 43: W07410. DOI: 10.1029/ 2005WR004816. 